\title{
Morphological and biochemical differences in three Undaria pinnatifida populations in Korea
}

\author{
Kwang-Jae Park ${ }^{1}$, Bo Yeon Kim² ${ }^{2}$, Seo Kyoung Park ${ }^{2}$, Jong-Hwa Lee ${ }^{3}$, Young Sik Kim4, \\ Han Gil Choi ${ }^{2, *}$ and Ki Wan Nam ${ }^{5}$ \\ ${ }^{1}$ Tidal Flat Research Institute, NFRDI, Kunsan 573-882, Korea \\ ${ }^{2}$ Faculty of Biological Science and Institute of Basic Natural Sciences, Wonkwang University, Iksan 570-749, Korea \\ ${ }^{3}$ Department of Aquaculture and Aquatic Science, Kunsan National University, Kunsan 573-701, Korea \\ ${ }^{4}$ Department of Marine Biotechnology, Kunsan National University, Kunsan 573-701, Korea \\ ${ }^{5}$ Department of Marine Biology, Pukyong National University, Busan 608-737, Korea
}

Twelve morphological characters and the biochemical composition of Undaria pinnatifida f. distans sporophytes growing on the rocky shores of Jindo and Wando and on cultivation ropes in Kijang were measured to determine whether each population could be characterized by morphological features and biochemical composition. The goal of this study was to compare phenotypic variations between populations as they relate to environmental conditions. The sporophytes of the Kijang population were two times longer and 19 times heavier than those at Jindo. Sporophylls of the Jindo U. pinnatifida population were significantly smaller in length, width, frill number, and weight than those at Wando and Kijang. Kijang Undaria plants showed the highest contents of total protein, crude fiber, total amino acids, the amount of essential amino acids, the proportion of total unsaturated fatty acids, and eicosapentaenoic acid. However, the Jindo population showed the greatest content of carbohydrates, lipids, and minerals ( $\mathrm{Zn}$ and $\mathrm{Ca}$ ) of the three $U$. pinnatifida populations. In particular, Zn content of Jindo plants was 30 times greater than that of Kijang plants. Thus, the proximate composition, mineral composition, amino acids, and fatty acids of Undaria pinnatifida plants were distinguishable among the three representative Undaria populations evaluated. These results suggest that morphological and biochemical differences of the three $U$. pinnatifida populations can be attributed to differences in environmental conditions of their habitats.

Key Words: biochemical composition; morphology; population; sporophyll; Undaria pinnatifida

\section{INTRODUCTION}

Undaria pinnatifida (Harvey) Suringar, called "miyok" in Korean, is a brown alga and a food source for marine animals and humans and is also used as a nursery environment for many marine organisms (Yamanaka and Akiyama 1993, Sohn 1998). In general, the alga is divided into southern and northern types based on morphological features (Okamura 1915, Taniguchi et al. 1981, Stuart et al. 1999). The southern type, U. pinnatifida f. typica Yendo, has a short stipe, shallow pinnate division of the blade, and sporophyll development that is often confluent with the base of the blade. The northern type, U. pinnatifida f. distans Miyabe \& Okamura, is characterized by an elongated stipe and a deeply divided blade, with sporophyll development confined to the basal portion (c) This is an Open Access article distributed under the terms of the Creative Commons Attribution Non-Commercial License (http://creativecommons.org/licenses/by-nc/3.0/) which permits unrestricted non-commercial use, distribution, and reproduction in any medium, provided the original work is properly cited.
Received July 21, 2012, Accepted August 18, 2012

*Corresponding Author

E-mail: hgchoi@wku.ac.kr

Tel: +82-63-8506579, Fax: +82-63-8578837 
of the stipe (Kito et al. 1981, Akiyama and Kurogi 1982, Ohno and Matsuoka 1993). Morphological characters used to distinguish $U$. pinnatifida $\mathrm{f}$. distans from f. typica are midrib width, stipe length, the degree of pinnate division, and sporophyll position on the stipe (Kito et al. 1981, Taniguchi et al. 1981).

It is well known that the morphological features of the two types of $U$. pinnatifida are related to environmental factors (Saito 1960, Taniguchi et al. 1981, Sohn 1984). Saito (1962) reported that stipe length and plant length are stable morphological features, irrespective of environmental conditions. Additionally, the transplanted descendants of the two U. pinnatipida types grown in the same environmental conditions remain distinguishable by pinnule length, incision depth, midrib width, plant length, and plant weight (Kito et al. 1981, Hara and Akiyama 1985, Lee and Sohn 1993). The sporophytes of the two Undaria types also differ in morphological features and blade color (dark brown in the northern type; light brown in the southern type) at similar ages and are 20-22 cm long (Hay and Villouta 1993, Castric-Fey et al. 1999). The two Undaria types also differ in the physiology of the gametophyte and sporophyte stages (Akiyama 1965, Kim and Nam 1997, Castric-Fey et al. 1999).

U. pinnatifida is an important nutrient source for diet and food additives because of their high content of minerals, trace elements, proteins, lipids, and carbohydrates (Rhee 1972, Hong et al. 1991, Lee 2004, Manivannan et al. 2008). Nutritional content varies with species, geographical location, season and temperature in seaweeds (Solimabi et al. 1980, Dawes et al. 1993, Kaehler and Kennish 1996). In U. pinnatifida, the proximate composition, alginic acid, and mineral content are different among the plant parts such as the frond, stipe, and sporophyll (Rhee 1972, Lee 2004). Thus, we expect that the proximate, mineral, amino acid, and fatty acid compositions will be different among $U$. pinnatifida populations grown under different environmental conditions. The nutritional value of edible $U$. pinnatifida is very beneficial for pregnant woman, adolescents, and elderly, which are all exposed to a risk for nutritional deficiency such as fatty acids and calcium.

Morphological differences are also found within the U. pinnatifida f. distans populations cultivated in Korea (Sohn 1984). The sporophytes of U. pinnatifida f. distans grow well in wave-exposed areas, as do their natural populations. Cultivation of U. pinnatifida was initially attempted in Kijang, with Kijang miyok now obtaining the highest price among cultivated $U$. pinnatifida products in Korea. Additionally, natural U. pinnatifida f. distans

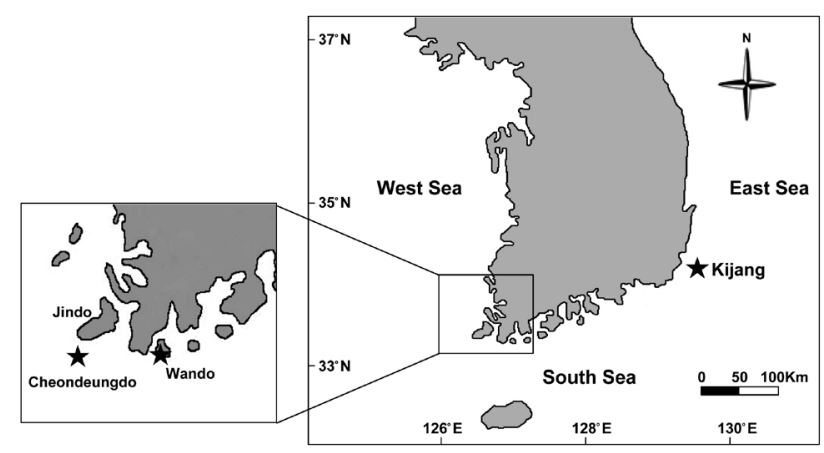

Fig. 1. Sampling areas ( $\star$ ) for the Undaria pinnatifida sporophytes.

sporophytes from Wando and Jindo are well known because for their high quality texture and nutrition (Im et al. 2006). The harvesting periods of native and cultivated $U$. pinnatifida sporophytes are generally between March and early April, but that of the Jindo population is from the end of July to early August. Thus, the Kijang, Wando, and Jindo $U$. pinnatifida populations are representative northern type populations in Korea. The aims of this study were to test whether the three $U$. pinnatifida f. distans populations could be characterized by morphological features and biochemical composition and to compare phenotypic variations among the populations based on environmental conditions.

\section{MATERIALS AND METHODS}

Sporophytes of $U$. pinnatifida were collected from a cultivation area near Kijang on the eastern coast of Korea in March 2006. U. pinnatifida sporophytes were collected from the rocky shores of Wando (a natural habitat) in April 2006 and from Jindo in July 2006 (Fig. 1). The collection time differed based on harvesting periods for these areas, but they were all at the same developed sporophyll stage. The Undaria sporophytes sampled at Chungdeungdo, Jindo, Korea were different in morphology (Fig. 2) compared to that of the Wando and Kijang plants, which have the morphological features described in Fig. 3. Morphological characters including plant and sporophyll weights were measured in 25 plants selected randomly from each population (Fig. 3). Plant weight including the sporophyll was estimated, and then the sporophylls were cut for weighing. The midrib thickness of U. pinnatifida was measured with a digital Vernier caliper (Mitutoyo, Tokyo, Japan).

A one-way analysis of variance was applied to compare 


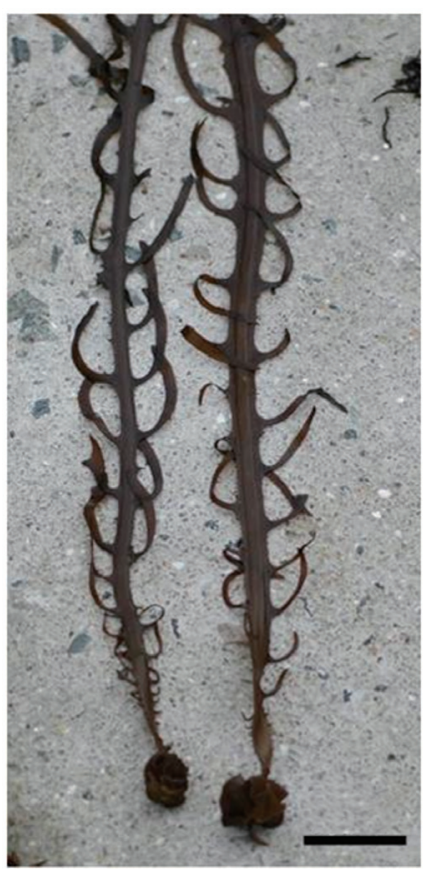

Fig. 2. Morphological features of Undaria pinnatifida collected at Chungdeungdo of Jindo, Korea. Scale bar represents: $5 \mathrm{~cm}$.

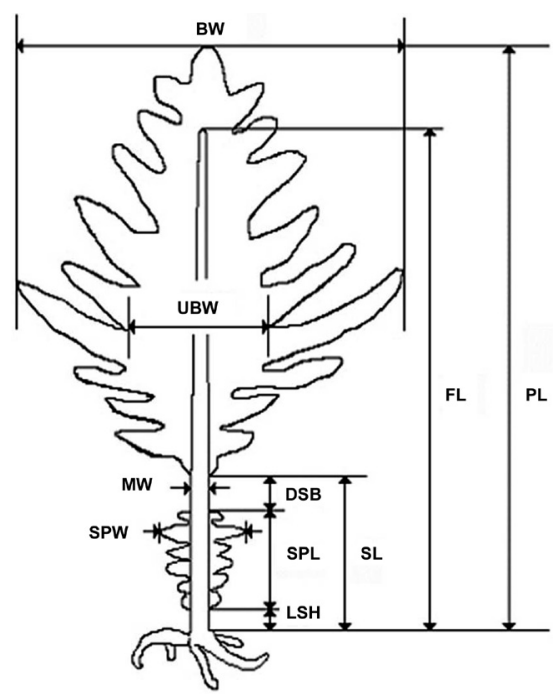

Fig. 3. Undaria pinnatifida morphometric measurements. PL, plant length; $\mathrm{FL}$, frond length; BW, blade width; UBW, undivided blade width; MW, midrib width; SL, stipe length; SPW, sporophyll width; $\mathrm{SPL}$, sporophyll length; DSB, distance between sporophyll and blade; $\mathrm{LSH}$, length between sporophyll and holdfast.

morphological parameters among the three Undaria populations, including plant and sporophyll weights. Prior to analysis, homogeneity of variance was tested using
Cochran's test, and data were transformed when necessary (Underwood 1997). Tukey's multiple comparison test was applied when significant differences between means were detected $(\mathrm{p}<0.05)$ (Sokal and Rohlf 1995). Statistical analyses were carried out using STATISTICA version 5.0 (Statsoft, Tulsa, OK, USA).

\section{Biochemical composition}

Moisture content of $U$. pinnatifida samples was determined after drying in an oven at $105^{\circ} \mathrm{C}$ until a constant weight was obtained, and ash content was estimated after overnight heating at $550^{\circ} \mathrm{C}$. Crude lipid was extracted in a Soxhlet extractor (SX-6; Raypa Co., Catalonia, Spain), and protein content was examined with an automatic Kjeldahl analyzer (B-339; Buchi Co., Flawil, Switzerland). Fiber content was analyzed by the method of Henneberg Stohmann (Minowa et al. 1995). Carbohydrate was calculated by the following equation (Dubois et al. 1956): \% carbohydrate $=100-$ (moisture + crude ash + crude lipid + crude protein + crude fiber). Mineral analyses were carried out on samples digested with nitric acid. Major mineral elements ( $\mathrm{Ca}, \mathrm{Mg}, \mathrm{K}$, and $\mathrm{Na}$ ) and trace elements $(\mathrm{Fe}, \mathrm{Cu}$, and $\mathrm{Zn}$ ) were measured by atomic absorption spectrophotometry (Solaar-M5; Thermo Elemental Co., East Anglia, England). Total phosphorus was measured using a spectrophotometer (UV- 1601; Shimadzu Co., Tokyo, Japan) according to the method of Topping (1972). Samples for amino acid analysis were hydrolyzed in 15 $\mathrm{mL}$ of $6 \mathrm{~N} \mathrm{HCl}$ at $110^{\circ} \mathrm{C}$ for $24 \mathrm{~h}$ in a dry oven. The samples were subsequently evaporated using a vacuum rotary evaporator, filtered $(\emptyset, 0.2 \mu \mathrm{m})$, and then amino acids were determined with an amino acid analyzer (S433; Sykam, Eresing, Germany). Approximately $0.2 \mathrm{~g}$ of extracted lipid was methylated with $5 \mathrm{~mL}$ of $0.5 \mathrm{~N}$ methanolic $\mathrm{NaOH}$ solution followed by heating for $2 \mathrm{~min}$ and extracted with $n$-heptane. The methyl esters were quantified by a gas chromatograph $(6890 \mathrm{~N}$; Agilent Technology, Palo Alto, CA, USA) equipped with a flame ionization detector and a SP-2560 column $(100 \mathrm{~m} \times 0.25 \mathrm{~mm}$; film thickness, $0.20 \mu \mathrm{m})$. The initial temperature of column was $140^{\circ} \mathrm{C}$ for $5 \mathrm{~min}$, and temperature was programmed to increase by $4^{\circ} \mathrm{C} \mathrm{min}^{-1}$ to $240^{\circ} \mathrm{C}$. The final temperature was held for $19 \mathrm{~min}$. Injector and detector temperatures were set at $260^{\circ} \mathrm{C}$, the carrier gas was nitrogen $\left(\mathrm{N}_{2}\right)$, and flow rate was $0.8 \mathrm{~mL} \mathrm{~min}^{-1}$. Each fatty acid was identified by comparing its retention time with that of a methyl ester mixture (Sigma Chemical Co., St. Louis, MO, USA). Fatty acid contents were calculated using peak area percentages of total fatty acid content. 


\section{RESULTS}

\section{Plant characteristics}

Sporophyte weights of $U$. pinnatifida at the three locations were 17.70-330.75 g wet weight, and plant lengths were $61.06-106.70 \mathrm{~cm}$. Plant weights and lengths were significantly different among the three populations (Table 1). U. pinnatifida sporophytes growing on cultivation ropes at Kijang were two times longer and 19 times heavier than those of sporophytes of the native Jindo population. Average stipe lengths of $U$. pinnatifida sporophytes were $6.35-28.71 \mathrm{~cm}$, and differences in stipe length were also found among the three populations (Table 1). Blade width of Undaria sporophytes was seven times greater for cultivated plants in Kijang than those collected at Jindo. The undivided blade width of the Jindo population was significantly smaller than that of Wando and Kijang plants. Additionally, average midrib widths and thicknesses of sporophytes were quite similar between native $U$. pinnatifida populations but were significantly greater in Kijang sporophytes. The distance between the sporophylls and blade (DSB) was 3.67-11.85 cm, and it was significantly greater in the Wando and Kijang populations. The DSB of the Jindo population was significantly smaller than that of the other two populations. Sporo- phyll position on the stipe was different among all three populations. The sporophylls of native populations were positioned just above the holdfast. Length between the sporophyll and holdfast was quite similar among the native populations, but was significantly greater at Kijang than that of the other two populations (Table 1).

\section{Sporophyll characteristics}

The sporophyll features of the three $U$. pinnatifida sporophyte populations were different. Sporophyll width was largest at Kijang $(6.63 \mathrm{~cm})$ and smallest $(2.88 \mathrm{~cm})$ at Jindo. Sporophyll width of the Kijang population was two-fold greater than that of Jindo (Table 1). A Tukey's test revealed that thd sporophyll width of the Jindo population was significantly smaller than that of the other two populations (Table 1). Sporophyll lengths of $U$. pinnatifida were 2.40 $\mathrm{cm}$ at Jindo, $6.98 \mathrm{~cm}$ at Wando, and $18.02 \mathrm{~cm}$ at Kijang. Average sporophyll length was seven times greater at Kijang than that at Jindo (Table 1). Sporophyll weights of U. pinnatifida sporophytes were 2.63-21.00 g wet weight, which was seven times less at Jindo compared to that in the Kijang population. Thus, Jindo sporophylls were smaller in length, width, and weight than those at Wando and Kijang.

Table 1. Results of a one-way analysis of variance and Tukey's HSD tests for the 12 morphological features (mean \pm standard deviation, $n=25$ plants) of the three Undaria pinnatifida populations

\begin{tabular}{|c|c|c|c|c|c|}
\hline Characteristics & Jindo & Wando & Kijang & p-value & Transformation \\
\hline \multicolumn{6}{|l|}{ Vegetative parts } \\
\hline Wet weight (g) & $17.70 \pm 5.36^{\mathrm{a}}$ & $102.69 \pm 51.59^{\mathrm{b}}$ & $330.75 \pm 194.95^{\mathrm{c}}$ & $<0.001$ & LN \\
\hline Plant length (cm) & $61.06 \pm 19.60^{\mathrm{a}}$ & $81.42 \pm 21.76^{\mathrm{b}}$ & $106.70 \pm 24.06^{\mathrm{c}}$ & $<0.001$ & None \\
\hline Stipe length (cm) & $6.35 \pm 2.57^{\mathrm{a}}$ & $19.25 \pm 6.49^{\mathrm{b}}$ & $28.71 \pm 8.89^{\mathrm{c}}$ & $<0.001$ & LN \\
\hline Blade width (cm) & $8.34 \pm 4.60^{\mathrm{a}}$ & $43.33 \pm 12.21^{\mathrm{b}}$ & $58.86 \pm 19.63^{\mathrm{c}}$ & $<0.001$ & LN \\
\hline UBW (cm) & $1.47 \pm 0.46^{\mathrm{a}}$ & $4.53 \pm 1.94^{\mathrm{b}}$ & $5.64 \pm 2.77^{\mathrm{b}}$ & $<0.001$ & $\mathrm{LN}+1$ \\
\hline Midrib width (cm) & $1.14 \pm 1.65^{\mathrm{a}}$ & $1.26 \pm 0.38^{\mathrm{a}}$ & $1.98 \pm 0.40^{\mathrm{b}}$ & $<0.001$ & $\mathrm{LN}+1$ \\
\hline Midrib thickness (mm) & $3.16 \pm 0.47^{\mathrm{a}}$ & $3.32 \pm 0.69^{\mathrm{a}}$ & $9.00 \pm 1.26^{\mathrm{b}}$ & $<0.001$ & $\mathrm{LN}$ \\
\hline $\mathrm{DSB}(\mathrm{cm})$ & $3.67 \pm 1.66^{\mathrm{a}}$ & $11.85 \pm 5.98^{\mathrm{b}}$ & $10.25 \pm 9.23^{b}$ & $<0.001$ & $\mathrm{LN}+1$ \\
\hline LSH (cm) & $1.00^{\mathrm{a}}$ & $1.00^{\mathrm{a}}$ & $2.45 \pm 1.35^{\mathrm{b}}$ & $<0.001$ & $\mathrm{LN}+1$ \\
\hline \multicolumn{6}{|l|}{ Reproductive parts } \\
\hline Sporophyll width (cm) & $2.88 \pm 0.99^{\mathrm{a}}$ & $5.54 \pm 1.23^{\mathrm{b}}$ & $6.63 \pm 1.90^{\mathrm{b}}$ & $<0.001$ & $\mathrm{LN}$ \\
\hline Sporophyll length (cm) & $2.40 \pm 0.55^{\mathrm{a}}$ & $6.98 \pm 1.88^{\mathrm{b}}$ & $18.02 \pm 7.83^{\mathrm{c}}$ & $<0.001$ & LN \\
\hline Sporophyll weight (g) & $2.63 \pm 1.30^{\mathrm{a}}$ & $16.92 \pm 8.42^{\mathrm{b}}$ & $21.00 \pm 8.22^{\mathrm{b}}$ & $<0.001$ & LN \\
\hline
\end{tabular}

Means in rows with different letter superscripts $(a-c)$ are significantly different $(p<0.05)$.

HSD, honestly significant difference; UBW, undivided blade width; DSB, distance between sporophyll and blade; LSH, length between sporophyll and holdfast. 


\section{Biochemical composition}

Proximate compositions of Undaria pinnatifida populations were $18.16-21.32 \%$ for protein, $28.57-33.35 \%$ for carbohydrates, and $1.50-1.74 \%$ for lipids (Table 2). Crude protein, fiber, and ash contents of $U$. pinnatifida were greater in the Kijang samples (21.32, 2.68, and 34.74\%, respectively) than those of the Wando and Jindo samples but lipids were not different among the three $U$. pinnatifida samples. Carbohydrate and moisture contents of $U$. pinnatifida were 28.57-33.35 and 11.27-12.53\%, respectively, and were significantly highest in the Jindo samples.

Undaria pinnatifida was rich in calcium, phosphorus, magnesium, potassium, and sodium (Table 3). Calcium and zinc content in the Jindo samples was 969.02 and $1.24 \mathrm{mg} 100 \mathrm{~g}^{-1}$ dry weight, respectively, which was the highest among the three Undaria samples. In particular, zinc content of Jindo plants was 30 times greater than that of Kijang plants. Sodium content in the Kijang sam-

Table 2. Proximate composition (\%; mean \pm standard deviation, $\mathrm{n}=3$ plants) of Undaria pinnatifida collected at Jindo, Wando, and Kijang

\begin{tabular}{lrrr}
\hline Composition & \multicolumn{1}{c}{ Jindo } & \multicolumn{1}{c}{ Wando } & \multicolumn{1}{c}{ Kijang } \\
\hline Crude protein & $18.16 \pm 0.98^{\mathrm{c}}$ & $19.32 \pm 0.96^{\mathrm{b}}$ & $21.32 \pm 0.80^{\mathrm{a}}$ \\
Crude lipid & $1.74 \pm 0.38^{\mathrm{a}}$ & $1.64 \pm 0.25^{\mathrm{a}}$ & $1.50 \pm 0.36^{\mathrm{a}}$ \\
Crude fiber & $2.41 \pm 0.31^{\mathrm{b}}$ & $2.51 \pm 0.27^{\mathrm{b}}$ & $2.68 \pm 0.43^{\mathrm{a}}$ \\
Crude ash & $31.81 \pm 1.02^{\mathrm{b}}$ & $32.07 \pm 0.86^{\mathrm{b}}$ & $34.74 \pm 0.72^{\mathrm{a}}$ \\
Carbohydrate & $33.35 \pm 1.54^{\mathrm{a}}$ & $32.84 \pm 1.72^{\mathrm{b}}$ & $28.57 \pm 1.69^{\mathrm{c}}$ \\
Moisture & $12.53 \pm 0.56^{\mathrm{a}}$ & $11.63 \pm 0.58^{\mathrm{b}}$ & $11.27 \pm 0.66^{\mathrm{b}}$ \\
\hline
\end{tabular}

Means in rows with different letter superscripts (a-c) are significantly different $(p<0.05)$.

Table 3. Mineral composition ( $\mathrm{mg} 100 \mathrm{~g}^{-1}$ dry weight, $\mathrm{n}=3$ plants) of the brown alga Undaria pinnatifida collected at Jindo, Wando, and Kijang

\begin{tabular}{lrrr}
\hline Mineral & Jindo & Wando & Kijang \\
\hline Calcium & 969.02 & 904.31 & 758.53 \\
Phosphorus & 497.32 & 499.82 & 418.54 \\
Magnesium & 832.25 & 925.37 & 885.53 \\
Potassium & $2,601.16$ & $4,156.95$ & $5,631.05$ \\
Sodium & $4,975.34$ & $5,840.00$ & $6,539.93$ \\
Iron & 5.79 & 9.50 & 6.38 \\
Copper & 0.08 & 0.19 & 0.16 \\
Zinc & 1.24 & 1.07 & 0.04 \\
\hline
\end{tabular}

ple exhibited the greatest value. The Wando sample had the highest mineral content such as phosphorus, magnesium, iron, and copper (499.82, 925.37, 9.50, and 0.19 mg $100 \mathrm{~g}^{-1} \mathrm{DW}$, respectively).

All $U$. pinnatifida plants collected from the three different rocky shores had seven essential amino acids (Table 4), including threonine, valine, methionine, isoleucine, leucine, phenylalanine, and lysine. Except for cystine, all amino acids exhibited their highest levels in the Kijang samples and the lowest levels in the Jindo samples. Additionally, the amount of essential and total amino acids was maximal in the Kijang sample (44.19 and $122.40 \mathrm{mg}$ $\mathrm{g}^{-1} \mathrm{DW}$, respectively) and minimal in the Jindo sample (28.72 and $82.63 \mathrm{mg} \mathrm{g}^{-1} \mathrm{DW}$, respectively). These results were in agreement with the patterns of crude protein content in the three $U$. pinnatifida populations.

Plants collected from the three $U$. pinnatifida populations were rich in saturated fatty acids such as palmitic acid, C16:0 (15.36-30.20\%), and unsaturated fatty acids such as oleic acid, C18:1 (7.97-24.68\%), and arachidonic acid, C20:4 (10.16-14.48\%). The proportion of essential fatty acids was highest in the Wando sample (41.61\%) followed by Jindo (39.45\%), and then the Kijang sample at $27.00 \%$. In contrast, the proportion of total unsaturated fatty acids was the greatest in the Kijang sample (74.86\%)

Table 4. Amino acid ( $\mathrm{mg} \mathrm{g}^{-1}$ dry weight, $\mathrm{n}=3$ plants) of the brown alga Undaria pinnatifida collected at Jindo, Wando, and Kijang

\begin{tabular}{lrrr}
\hline Amino acid & Jindo & Wando & Kijang \\
\hline Aspartic acid & 8.77 & 10.38 & 12.61 \\
Threonine $^{\mathrm{a}}$ & 4.41 & 4.85 & 6.05 \\
Serine & 4.54 & 4.88 & 5.87 \\
Glutamic acid & 12.11 & 13.95 & 17.81 \\
Proline & 3.76 & 4.33 & 5.54 \\
Glycine & 5.39 & 5.93 & 7.26 \\
Alanine & 9.17 & 12.54 & 14.82 \\
Cystine & 0.27 & 0.16 & 0.14 \\
Valine $^{\mathrm{a}}$ & 3.22 & 5.22 & 6.75 \\
Methionine & 1.72 & 2.08 & 2.83 \\
Isoleucine $^{\mathrm{a}}$ & 3.71 & 4.12 & 5.57 \\
Leucine $^{\mathrm{a}}$ & 6.55 & 7.50 & 9.93 \\
Tyrosine $_{\text {Phenylalanine }}^{\mathrm{a}}$ & 2.76 & 3.12 & 4.09 \\
Histidine $_{\text {Lysine }}^{\mathrm{a}}$ & 4.11 & 4.61 & 6.15 \\
Arginine $^{\mathrm{a}}$ & 2.35 & 2.62 & 3.17 \\
Essential amino acid. & & 5.36 & 6.91 \\
& 5.00 & 5.38 & 6.90 \\
\hline
\end{tabular}


and the least in the Jindo population (Table 5). Additionally, eicosapentaenoic acid (EPA), an n-3 polyunsaturated fatty acid, was two times greater in Kijang plants than that in the Jindo and Wando plants.

\section{DISCUSSION}

Morphological features of U. pinnatifida f. distans sporophytes and sporophylls were significantly different among the Kijang, Wando, and Jindo populations. In particular, plant length and weight of the cultivated $U$. pinnatifida sporophytes at Kijang were two times longer (106 $\mathrm{cm})$ and 19 times heavier (330 g) than the sporophytes of

Table 5. Fatty acid composition (\%) of the brown alga $(n=3$ plants) Undaria pinnatifida collected at Jindo, Wando, and Kijang

\begin{tabular}{|c|c|c|c|}
\hline Fatty acid & Jindo & Wando & Kijang \\
\hline Myristic acid (14:0) & 4.67 & 4.65 & 4.01 \\
\hline Pentadecanoic acid (15:0) & 0.19 & 0.21 & 0.3 \\
\hline Palmitic acid (16:0) & 27.31 & 30.2 & 15.36 \\
\hline Palmitoleic acid (16:1) & 0.81 & 1.17 & 1.24 \\
\hline Heptadecanoic acid (17:0) & 0.49 & 1.12 & 2.01 \\
\hline Heptadecanoic acid (17:1) & Trace & 0.23 & 0.34 \\
\hline Stearic acid (18:0) & 2.79 & 6.91 & 3.08 \\
\hline Oleic acid $(18: 1)^{\mathrm{a}}$ & 16.83 & 24.68 & 7.97 \\
\hline Linoleic acid $(18: 2)^{\mathrm{a}}$ & 8.14 & 6.77 & 5.86 \\
\hline Linolenic acid (18:3) & 8.16 & 5.49 & 11.57 \\
\hline Arachidic acid (20:0) & 0.74 & 0.68 & 0.38 \\
\hline Eicosadienoic acid (20:2) & 9.17 & 1.44 & 23.05 \\
\hline Eicosatrienoic acid (20:3) & 0.87 & 0.52 & 0.45 \\
\hline Arachidonic acid $(20: 4)^{\mathrm{a}}$ & 14.48 & 10.16 & 13.17 \\
\hline Eicosapentaenoic (20:5) & 5.35 & 5.77 & 11.21 \\
\hline Total saturated & 36.19 & 43.77 & 25.14 \\
\hline Total unsaturated & 63.81 & 56.23 & 74.86 \\
\hline
\end{tabular}

${ }^{a}$ Essential fatty acid. the Jindo population ( $61 \mathrm{~cm}$ and $18 \mathrm{~g}$, respectively). Choi et al. (2007) reported that mean plant lengths and weights of $U$. pinnatifida sporophytes grown in a Busan cultivation farm were $109 \mathrm{~cm}$ and $372 \mathrm{~g}$ in March 1996, respectively. Sporophyll weight was seven times lighter at Jindo (3 g wet weight) compared to that in the Kijang population $(21 \mathrm{~g})$. Jindo sporophylls were also eight times smaller in length than those at Kijang. These results show that $U$. pinnatifida sporophytes have different morphological features among the three populations, which may be related to the environmental conditions of their habitats.

Kijang Undaria plants showed the highest total protein, crude fiber, and total amino acid contents, and in the amount of essential amino acids and the proportion of total unsaturated fatty acids and EPA. However, the Jindo population revealed the greatest carbohydrate, lipid, and mineral ( $\mathrm{Zn}$ and $\mathrm{Ca}$ ) contents of the three $U$. pinnatifida populations. In particular, Zn content of Jindo plants was 30 times greater than that of Kijang plants. Thus, the proximate composition, mineral composition, amino acid, and fatty acids of Undaria pinnatifida plants were distinguishable among the three representative $U n$ daria populations evaluated. These results also indicate that these edible seaweeds contain significant nutritional value, such as protein and minerals, and that nutrient content varied according to environmental conditions of their habitat even within the same species (Dawes et al. 1993, Kaehler and Kennish 1996, Manivannan et al. 2008).

The morphological features and chemical composition of $U$. pinnatifida sporophytes varied among the three populations grown under different environmental conditions. Most environmental data were very similar among the study sites but total nitrogen, dissolved inorganic nitrogen, total phosphorous, and dissolved inorganic phosphorous were slightly higher at Jindo compared to those at Kijang (Table 6). The Jindo site was wave-exposed, whereas the Wando and Kijang sites were semi-exposed. In the present results, plant length, weight, and undivided

Table 6. Annual average values of environmental data collected at the seawater surface around the coastal area of the three sampling sites of Undaria pinnatifida sporophytes

\begin{tabular}{lcccccccrc}
\hline & $\begin{array}{c}\text { Temperature } \\
\left({ }^{\circ} \mathrm{C}\right)\end{array}$ & $\begin{array}{c}\text { Salinity } \\
(\mathbf{p p t})\end{array}$ & $\begin{array}{c}\mathrm{DO} \\
\left(\mathrm{mg} \mathrm{L}^{-1}\right)\end{array}$ & $\begin{array}{c}\mathrm{COD} \\
\left(\mathrm{mg} \mathrm{L}^{-1}\right)\end{array}$ & $\begin{array}{c}\mathrm{TN} \\
\left(\mathrm{mg} \mathrm{L}^{-1}\right)\end{array}$ & $\begin{array}{c}\text { DIN } \\
\left(\mathrm{mg} \mathrm{L}^{-1}\right)\end{array}$ & $\begin{array}{c}\text { TP } \\
\left(\mathrm{mg} \mathrm{L}^{-1}\right)\end{array}$ & $\begin{array}{c}\text { DIP } \\
\left(\mathrm{mg} \mathrm{L}^{-1}\right)\end{array}$ & $\begin{array}{c}\text { Wave } \\
\text { exposure }\end{array}$ \\
\hline Jindo & 14.99 & 33.44 & 7.89 & 0.86 & 0.56 & 0.20 & 0.05 & 0.02 & Exposed \\
Wando & 15.59 & 33.55 & 8.18 & 0.81 & 0.60 & 0.19 & 0.04 & 0.02 & Semi-exposed \\
Kijang & 16.47 & 33.36 & 8.96 & 1.02 & 0.21 & 0.09 & 0.02 & 0.01 & Semi-exposed \\
\hline
\end{tabular}

DO, dissolved oxygen; COD, chemical oxygen demand; TN, total nitrogen, DIN, dissolved inorganic nitrogen; TP, total phosphorus; DIP, dissolved inorganic phosphorous. 
blade width of $U$. pinnatifida sporophytes were smaller in the wave-exposed Jindo population than those in the semi-exposed Wando and Kijang populations. In previous studies, $U$. pinnatifida morphology changed due to environmental conditions (water depth, seawater temperature, and currents), and U. pinnatifida sporophytes are shorter and slimmer to survive in strong current areas (Saito 1960, Ii 1964). Thus, such different morphological and chemical composition are possibly attributed to differences in wave exposure, which changes plant morphology by direct physical conditions and changes the chemical composition of plants by indirectly providing different levels of inorganic nitrogen and phosphate .

However, frond length, the number of pinnae / frond length, and the number of sporophyll frills are stable morphological characters in U. pinnatifida transplant experiments, and do not change due to environmental factors (Saito 1972). Kito et al. (1981) reported that the stable morphological features related to the genetics of $U$. pinnatifida are midrib width and the length of the longest pinnate blade. Saito (1962) indicated that stipe length, total plant length, and the number of pinnate blades: total plant ratios are genetically fixed. In the present study, midrib width and plant length were significantly smaller at Jindo than those at Kijang, suggesting genetic differences between the two U. pinnatifida populations.

A genetic diversity study of Jindo and Kijang Undaria populations is required to understand whether their morphological differences originate from genetic differences. Additionally, proximate composition, mineral composition, amino acids, and fatty acids of $U$. pinnatifida were distinguishable among the three representative Undaria populations tested. Thus, we suggest that morphological and biochemical differences in the three $U$. pinnatifida populations might originate from different environmental conditions of their habitats.

\section{ACKNOWLEDGEMENTS}

We would like to thank anonymous reviewers for helpful comments which improved the manuscript. This paper was supported by Wonkwang University in 2012.

\section{REFERENCES}

Akiyama, K. 1965. Studies of ecology and culture of Undaria pinnatifida (Harv.) Sur. II. Environmental factors affecting the growth and maturation of gametophyte. Bull. Tohoku Reg. Fish. Res. Lab. 25:143-170.
Akiyama, K. \& Kurogi, M. 1982. Cultivation of Undaria pinnatifida (Harvey) Suringar, the decrease in crops from natural plants following crop increase from cultivation. Bull. Tohoku Reg. Fish. Res. Lab. 44:91-100.

Castric-Fey, A., Beaupoil, C., Bouchain, J., Pradier, E. \& L'Hardy-Halos, M. Th. 1999. The introduced alga Undaria pinnatifida (Laminariales, Alariaceae) in the rocky shore ecosystem of the St Malo area: morphology and growth of the sporophyte. Bot. Mar. 42:71-82.

Choi, H. G., Kim, Y. S., Lee, S. J. \& Nam, K. W. 2007. Growth and reproductive patterns of Undaria pinnatifida sporophytes in a cultivation farm in Busan, Korea. J. Appl. Phycol. 19:131-138.

Dawes, C. J., Kovach, D. \& Friedlander, M. 1993. Exposure of Gracilaria to various environmental conditions. II. The effect on fatty acid composition. Bot. Mar. 36:289-296.

Dubois, M., Gilles, K. A., Hamilton, J. K., Rebors, P. A. \& Smith, F. 1956. Calorimetric method for determination of sugars and related substances. Anal. Chem. 28:350-356.

Hara, M. \& Akiyama, K. 1985. Heterosis in growth of Undaria pinnatifida (Harvey) Suringar. Bull. Tohoku Reg. Fish. Res. Lab. 47:47-50.

Hay, C. H. \& Villouta, E. 1993. Seasonality of the ypicales Asian kelp Undaria pinnatifida in New Zealand. Bot. Mar. 36:461-476.

Hong, J. -S, Kwon, Y. -J., Kim, Y. -H., Kim, M. -K., Park, I. -W. \& Kang, K. -H. 1991. Fatty acid composition of Miyeok (Undaria pinnatifida) and Pare (Enteromorpha compressa). J. Korean Soc. Food. Nutr. 20:376-380.

Ii, A. 1964. The textbook of "Wakame"(Undaria pinnatifida) culture. Hyogo Prefecture, Federation of Fisheries Cooperative Association, Kobe, $41 \mathrm{pp}$.

Im, Y. -G., Choi, J. -S. \& Kim, D. -S. 2006. Mineral contents of edible seaweeds collected from Gijang and Wando in Korea. J. Korean Fish. Soc. 39:16-22.

Kaehler, S. \& Kennish, R. 1996. Summer and winter comparisons in the nutritional value of marine macroalgae from Hong Kong. Bot. Mar. 39:11-17.

Kim, Y. S. \& Nam, K. W. 1997. Temperature and light responses on the growth and maturation of gametophytes of Undaria pinnatifida (Harvey) Suringar in Korea. J. Korean Fish. Soc. 30:505-510.

Kito, H., Taniguchi, K. \& Akiyama, K. 1981. Morphological variation of Undaria pinnatifida (Harvey) Suringar. II. Comparison of the thallus morphology of cultured F1 plants originated from parental types of two different morphologies. Bull. Tohoku Reg. Fish. Res. Lab. 42:1118.

Lee, K. Y. \& Sohn, C. H. 1993. Morphological characteristics and growth of two forms of sea mustard, Undaria pin- 
natifida f. distans and $U$. pinnatifida f. typica. J. Aquac. 6:71-87.

Lee, Y. -J. 2004. A study on mineral and alginic acid contents by different parts of sea mustards (Undaria pinnatifida). Korean J. Food Cult. 19:691-700.

Manivannan, K., Thirumaran, G., Devi, G. K., Hemalatha, A. \& Anantharaman, P. 2008. Biochemical composition of seaweeds from Mandapam coastal regions along Southeast Coast of India. Am.-Eurasian J. Bot. 1:32-37.

Minowa, T., Yokoyama, S. -Y., Kishimoto, M. \& Okakura, T. 1995. Oil production from algal cells of Dunaliella tertiolecta by direct thermochemical liquefaction. Fuel 74:1735-1738.

Ohno, M. \& Matsuoka, M. 1993. Undaria cultivation 'Wakame'. In Ohno, M. \& Critchley, A. T. (Eds.) Seaweed Cultivation and Marine Ranching. Japan International Cooperation Agency, Yokosuka, pp. 41-49.

Okamura, K. 1915. Undaria and its species. Bot. Mag. Tokyo 29:266-278.

Rhee, S. -H. 1972. A study on the calcium and iron content of the Undaria pinnatifida Suringar. J. Korean Soc. Food. Nutr. 1:25-31.

Saito, Y. 1960. An ecological study of Undaria pinnatifida SUR. V. On the shape of cultured fronds-1. Bull. Jpn. Soc. Sci. Fish. 26:250-258.

Saito, Y. 1962. Fundamental studies on the propagation of Undaria pinnatifida (Harv.) Sur. Contrib. Fish. Lab. Fac. Agric. Univ. Tokyo 3:1-101.

Saito, Y. 1972. On the effects of environmental factors on morphological characteristics of Undaria pinnatifida and the breeding of hybrids in the genus Undaria. In Abbott, I. A. \& Kurogi, M. (Eds.) Contributions to the Systematics of Benthic Marine Algae of the North Pacific: Proceedings of a Seminar on the Contributions of Culture, Laboratory, Field and Life History Studies to the Sys- tematics of Benthic Marine Algae of the Pacific. Japanese Society of Phycology, Kobe, pp. 117-131.

Sohn, C. H. 1984. On the morphological variation of Undaria pinnatifida (Har.) Sur. Grown in the culture grounds at Onsan Bay, Korea. Bull. Nat. Fish. Univ. Pusan Nat. Sci. 24:5-12.

Sohn, C. H. 1998. The seaweed resources of Korea. In Critchley, A. T. \& Ohno, M. (Eds.) Seaweed Resources of the World. Kanagawa International Fisheries Training Center, Japan International cooperative Agency, Yokosuka, pp. 15-33.

Sokal, R. R. \& Rohlf, F. J. 1995. Biometry. 3rd ed. W. H. Freeman, New York, 887 pp.

Solimabi, B. D., Kamat, S. Y., Fernandes, L. \& Reddy, C. V. G. 1980. Seasonal changes in carrageenan and other biochemical constituents of Hypnea musciformis. Indian J. Mar. Sci. 9:134-136.

Stuart, M. D., Hurd, C. L. \& Brown, M. T. 1999. Effects of seasonal growth rate on morphological variation of Undaria pinnatifida (Alariaceae, Phaeophyceae). Hydrobiologia 398/399:191-199.

Taniguchi, K., Kito, H. \& Akiyama, K. 1981. Morphological variation of Undaria pinnatifida (Harvey) Suringer-I. On the difference of growth and morphological characteristics of two types at Matsushima Bay, Japan. Bull. Tohoku Reg. Fish. Res. Lab. 42:1-9.

Topping, G. 1972. Heavy metals in shellfish from Scottish waters. Aquaculture 1:379-384.

Underwood, A. J. 1997. Experiments in ecology: their logical design and interpretation using analysis of variance. Cambridge University Press, Cambridge, 504 pp.

Yamanaka, R. \& Akiyama, K. 1993. Cultivation and utilization of Undaria pinnatifida (wakame) as food. J. Appl. Phycol. 5:249-253. 